\title{
The influence of depressive symptoms and substance use on adherence to antiretroviral therapy. A cross-sectional prevalence study
}

\author{
A influência dos sintomas depressivos e do uso de substâncias na adesão \\ à terapia antirretroviral. Um estudo transversal de prevalência
}

\author{
Claudia Siqueira Tufano', Ricardo Abrantes do Amaral", Luciana Roberta Donola Cardoso'II, André Malbergier'V \\ Casa da AIDS, Medical School, Universidade de São Paulo (USP), São Paulo, Brazil
}

\author{
'Medical student. Universidade Anhembi \\ Morumbi, São Paulo, Brazil. \\ "MD, MSc, PhD. Lecturer at Medical School, \\ Universidade de São Paulo (USP), São Paulo, Brazil. \\ "'BSC, MSc. Postgraduate student at Medical \\ School, Universidade de São Paulo (USP), São \\ Paulo, Brazil. \\ "MD, MSc, PhD. Lecturer at Medical School, \\ Universidade de São Paulo (USP), São Paulo, Brazil.

\section{KEY WORDS:} \\ HIV. \\ Depression. \\ Medication adherence. \\ Antiretroviral therapy, highly active. \\ Immune system.
}

\section{PALAVRAS-CHAVE:}

HIV.

Depressão.

Adesão à medicação.

Terapia antirretroviral de alta atividade. Sistema imunológico.

\begin{abstract}
CONTEXT AND OBJECTIVE: Adherence to antiretroviral treatment (ART) is not a stable condition, but is dynamic, like mental conditions. The aim of this study was to examine whether non-adherence to ART is related to demographic and immunological variables, substance use and presence of depressive symptoms. DESIGN AND SETTING: This was a cross-sectional prevalence study carried out at a public AIDS treatment center in the city of São Paulo, Brazil, between July 2006 and January 2007.

METHODS: 438 patients on regular ART schedules with recent laboratory tests answered a demographic questionnaire, questions about substance use, the Hamilton Depression Rating Scale (HDRS) and the Simplified Medication Adherence Questionnaire (SMAQ).

RESULTS: The prevalence of non-adherence over the past three months (a pattern of treatment interruption) was $46.3 \%$, and $27.2 \%$ also reported this in the past week (a pattern of missed doses). ART interruption was significantly related to older age, lower CD4+ cell count and homosexual/bisexual transmission. The pattern of missed doses was significantly related to younger age, higher HDRS scores and higher viral load of RNA HIV.

CONCLUSION: ART interruption may reflect recall errors and changes to the Brazilian demographic characteristics of HIV infection. The missed doses may reflect lifestyle characteristics of younger individuals. Attendance for HIV-positive individuals, particularly younger patients, should involve interventions and counseling in relation to the presence of depressive symptoms.
\end{abstract}

\section{RESUMO}

CONTEXTO E OBJETIVO: Adesão ao tratamento antirretroviral (TARV) não é uma condição estável, mas dinâmica, como os transtornos mentais. O objetivo deste estudo foi verificar se a não adesão ao TARV relaciona-se às variáveis demográficas e imunológicas, ao uso de substâncias e à presença de sintomas depressivos.

DESENHO E LOCAL: Este estudo transversal de prevalência foi realizado em um serviço público para tratamento de pessoas HIV-positivas na cidade de São Paulo, Brasil, entre julho 2006 e janeiro 2007.

MÉTODOS: 438 pacientes em regime regular de TARV, que tinham exames laboratoriais recentes, responderam a questionário demográfico, questões sobre uso de substâncias, Escala de Hamilton para Depressão (HAM-D) e Questionário Simplificado de Adesão à Medicação (QSAM).

RESULTADOS: A prevalência de não adesão nos últimos três meses (um padrão de interrupção de tratamento) foi de $46,3 \%$ e de $27,2 \%$ na última semana (um padrão de perda de doses). A interrupção do TARV relacionou-se significativamente a maior idade, menor contagem de células CD4+ e contágio homo/bissexual, enquanto o padrão de perda de doses relacionou-se significativamente com idade mais jovem, pontuação mais alta na HAM-D e maior carga viral de RNA HIV.

CONCLUSÃO: A interrupção do TARV pode refletir erros de memória e mudanças nas características demográficas brasileiras da infecção por HIV. A perda de doses pode refletir aspectos de estilo de vida de indivíduos mais jovens. O atendimento de indivíduos HIV-positivos, particularmente os mais jovens, deve envolver intervenções e aconselhamento em relação à presença de sintomas depressivos. 


\section{INTRODUCTION}

Highly active antiretroviral therapy (HAART) is crucial for slowing down clinical progression and increasing survival among HIV-infected individuals. However, to achieve this clinical effect, adherence to HAART is necessary. ${ }^{1,2}$ Conceptually, adherence is "the extent to which the patient's behavior matches the prescriber's agreed recommendations". ${ }^{3}$

Among the multifactorial causes of non-adherence to antiretroviral therapy (ART) ${ }^{4}$ it has been observed that substance use $^{5-7}$ and depressive symptoms $s^{4,8}$ have an impact. Substance use disorders and mood disorders are the most common psychiatric diseases among HIV-positive patients, and have been shown to affect people living with HIV (PLWH) significantly more often than the general population. ${ }^{9}$ Additionally, stressful events and trauma have a negative effect on important components of the complex immune system, such as CD4 T cells. ${ }^{10,11}$

Since adherence is unstable in situations such as mental conditions ${ }^{12}$ with erratic ${ }^{13}$ and dynamic courses, ${ }^{14,15}$ or is expressed in other forms, such as missed doses or as treatment interruptions, i.e. so-called "drug holidays", ${ }^{16}$ early detection of non-adherence may prevent the development of ART resistance and treatment failure. ${ }^{17}$

In Brazil, few studies have investigated the impact of substance use or depressive symptoms on adherence to ART. Previous results showed that patients on ART may interrupt treatment to consume alcohol, ${ }^{18,19}$ or that using alcohol, tobacco and any illicit drug could be linked to a profile of higher vulnerability to non-adherence. ${ }^{20,21}$ The same vulnerability was observed for severe depressive symptoms ${ }^{22}$ or depression..$^{23}$

\section{OBJECTIVE}

The aim of this study was to examine whether non-adherence to ART over the past three months, also called treatment interruption (i.e. more than two days of interruption), and over the last week, also called missed doses, are associated with the same demographic and immunological variables and, particularly, with substance use over the past month and presence of depressive symptoms over the past week.

\section{METHODS}

\section{Study population}

This study was carried out by the Alcohol and Drug Study Group (GREA) of the psychiatric department of a medical school at a public university in the city of São Paulo, Brazil, and at the HIV treatment center (AIDS Clinic) affiliated to this medical school. Since 1994, this center has been providing multidisciplinary HIV/AIDS care on a 12-hour day outpatient basis. The center provides services relating to infectious diseases, gynecology, psychiatry, obstetrics, endoscopy, oral health, psychology, social work, nutrition and physical education. High-complexity patients are followed up in accordance with the Brazilian Ministry of Health protocols. ${ }^{24}$

The inclusion criteria for this study were that the patients needed to be over 18 years of age and on ART, and to have HIV-related laboratory data (CD4+ cell count and viral load) recorded within the last three months preceding the interview. The exclusion criteria were a clinical diagnosis of dementia or a score of less than 24 points on the Mini-Mental State Examination (MMSE). ${ }^{25}$

The study consisted of face-to-face interviews conducted by trained psychiatrists and psychologists. Every day, the first five patients scheduled for routine medical consultations were invited to participate in the study. All interviews were conducted in a private room and lasted approximately two hours. The study was carried out from July 2006 to January 2007.

A sample of 455 was obtained from the total population of patients under treatment $(\mathrm{N}=3,000)$, taking $20 \%$ to be the estimated prevalence of non-adherence to ART, alpha $=5 \%$, and a confidence interval (CI) of $95 \%$.

\section{Measurements criteria}

Alcohol and drug use was assessed over the preceding month. Last-month alcohol use was measured as none/less than once a week or more than once a week.

The Hamilton Depression Rating Scale (HDRS) ${ }^{26}$ was used to measure the presence of depressive symptoms.

The Simplified Medication Adherence Questionnaire $(\mathrm{SMAQ})^{27}$ was used to assess adherence to ART. SMAQ has a dichotomous structure and its questions can be assessed separately: (1) "Do you ever forget to take your medicine?"; (2) "Are you careless at times about taking your medicine?"; (3) "If at times you feel worse, do you stop taking your medicine?"; (4) "Thinking about the last week, how often have you not taken your medicine?"; (5) "Did you not take any of your medicine over the last weekend?"; (6) "Over the past three months, on how many days have you not taken any medicine at all?" The nonadherence was considered to be "positive" when a non-adherent patient was detected, i.e. when more than two doses were missed over the past week (Question 4) or over the last weekend (Question 5) (recent non-adherence, i.e. a pattern of missed doses), or more than two days of total non-medication during the past three months (Question 6) (non-adherence over the past three months, i.e. a pattern of treatment interruption).

\section{Clinical features}

The most recent CD4+ cell count and RNA HIV viral load registered in the patient's records were assessed. Plasma RNA viral 
load was described as $\log _{10}$ RNA copies/ml. Viral load was classified in categories as follows: detectable (HIV RNA copies $>40$ ) or undetectable (HIV RNA copies $\leq 40$ ).

\section{Statistical analysis}

The following variables were defined as predictive: gender (male or female); race/ethnicity (declared by the interviewee as white, black, mixed or other); education was defined as basic (up to 11 years of study) or higher (college or university level); working (yes or no); conjugal situation (living together or living alone); the form of HIV transmission was described as heterosexual sexual intercourse, homosexual/bisexual sexual intercourse, hemodialysis/transfusion (named intravenous HIV transmission) or unknown transmission route; alcohol consumption last month (none/less than once a week or more than once a week); cocaine use (no or yes); and cannabis use (no and yes). Continuous variables were described as means and standard deviation (SD); age and time since HIV seroconversion were described in years; annual income was described in United States (US) dollars (US dollar to Real exchange in January $2007=2.133$ ); HDRS score, number of $\mathrm{CD} 4+$ cells and viral load were described as above.

The outcome variable was adherence to ART, which was defined as adherence over the past three months (past adherence, treatment interruption; yes or no) and as adherence over the past week (recent adherence, missed doses; yes or no). Pearson's correlation between the two measurements of adherence was not significant ( $r=-0.002 ; \mathrm{P}=0.97$ ). Categorical data were described as percentages, and Pearson's chi-square test was used to make comparisons relating to past and recent adherence status. Student's t test was used for continuous variables relating to the measurements of adherence. A probability level below 5\% was considered statistically significant.

The magnitude of the correlation between predictive variables relating to past and recent ART non-adherence was measured by examining the crude odds ratio (OR) and the corresponding 95\% confidence intervals (CI). The best predictive models for past and recent non-adherence were built through multiple logistic regression analyses using stepwise selection for each adherence measurement. Independent variables with significant crude $\mathrm{OR}$ results $(\mathrm{P} \leq 0.1)$ were entered into the initial model. The data were analyzed using SPSS version 16.0 (SPSS Inc., Chicago, Illinois, USA).

\section{Ethical procedures}

This study was approved by the university's Ethics Committee. All subjects included in the study gave their informed consent prior to their inclusion. The project was supported by a grant (CSV 083/06) from the HIV/STD National Coordination Office of the Brazilian Ministry of Health.

\section{RESULTS}

\section{Demographics and clinical and adherence status of the sample}

Between July 2006 and January 2007, 459 patients on antiretroviral treatment were assessed. Twenty-one patients were excluded: three because of low MMSE scores ( $<24$ points) and eighteen because no CD4+ cell counts and HIV viral loads recorded over the last three months were available.

The 438 patients included in the study were predominantly white $(\mathrm{n}=251 ; 57.3 \%)$ and living alone $(\mathrm{n}=299 ; 68.3 \%)$. The mean age was 41.7 years (standard deviation, $\mathrm{SD} \pm 8.0$ ) and the gender distribution was approximately equal (males: $n=226$; $51.6 \%)$. Close to $75 \%$ of the sample had basic education and close to $25 \%$ had higher education. Almost $62 \%$ of the sample $(n=240)$ were working, and the mean annual income of those who were currently working or receiving a pension was US\$11,056 (SD: $\pm 10,428$ ), ranging from US\$ 1,283 to US\$ 91,397. The mean length of time since becoming aware of being HIV infected was 9.46 years (SD: \pm 4.7 ). The main form of HIV transmission was through heterosexual sexual intercourse $(\mathrm{n}=241 ; 55 \%)$. Twenty-seven percent of the sample $(\mathrm{n}=118)$ reported having become infected through homosexual/bisexual transmission, and $16 \%(\mathrm{n}=71)$ said that they did not know what their HIV transmission route was. The remaining $2 \%(n=8)$ of the sample reported intravenous HIV transmission. No patient reported injection drug use.

The mean CD4 cell count was 569.1/ml (318.4). Mean $\log _{10}$ RNA copies/ml among the sample was 1.96 (SD: \pm 1.2 ).

Over the preceding month, 364 patients (83.1\%) reported no alcohol use or use less than once a week. Last-month alcohol use more than once a week was reported by 74 individuals $(16.9 \%)$. Over the preceding month, almost $10 \%$ of the sample $(n=41)$ reported use of illicit drugs: $34(7.8 \%)$ reported cannabis use, 16 $(3.7 \%)$ cocaine use and $0.2 \%(\mathrm{n}=1)$ amphetamine use. Frequent recent use (more than once a week) of cannabis and cocaine were reported, respectively, by $5.1 \%(n=22)$ and $1.4 \%(n=6)$ of the sample. The mean score for the HDRS was 6.97 (SD: \pm 8.3 ). Overall, 319 patients (72.8\%) reported some pattern of non-adherence to ART. Three patients who reported past and recent nonadherence were included in the past non-adherent group (Table 1).

\section{Past non-adherence}

Two hundred and three patients $(46.3 \%)$ on ART reported past non-adherence. The correlation between past adherence and undetectable viral load was not significant (Pearson chisquare value $=0.038 ; \mathrm{P}=0.845 ; \mathrm{OR}=1.04 ; 95 \% \mathrm{CI}$ : 0.67-1.62) The mean age of past non-adherent patients was higher than that of the adherents (mean age 41.6 years). The likelihood of being nonadherent was almost $40 \%$ lower among higher-educated patients. 
Table 1. Total sample characteristics at the HIV treatment center, in 2007

\begin{tabular}{|c|c|}
\hline Characteristics & $\begin{array}{l}\text { Total sample } \\
n=438\end{array}$ \\
\hline Age in years, mean (SD) & $41.7(8.0)$ \\
\hline \multicolumn{2}{|l|}{ Gender, n (\%) } \\
\hline Male & $226(51.6)$ \\
\hline Female & $212(48.4)$ \\
\hline \multicolumn{2}{|l|}{ Race/ethnicity, n (\%) } \\
\hline White & $251(57.3)$ \\
\hline Black & $76(17.4)$ \\
\hline Mixed & $90(20.5)$ \\
\hline Other & $21(4.8)$ \\
\hline \multicolumn{2}{|l|}{ Education, $\mathrm{n}(\%)$} \\
\hline Basic & $331(75.6)$ \\
\hline Higher & $107(24.4)$ \\
\hline \multicolumn{2}{|l|}{ Working status, $\mathrm{n}(\%)$} \\
\hline Yes & $240(54.8)$ \\
\hline No & $198(45.2)$ \\
\hline Annual income in US dollars, mean (SD)* & $11,056(10,428)$ \\
\hline \multicolumn{2}{|l|}{ Conjugal status, $\mathrm{n}(\%)$} \\
\hline Living together & $139(31.7)$ \\
\hline Living alone & $299(68.3)$ \\
\hline \multicolumn{2}{|l|}{ HIV transmission route, $\mathrm{n}(\%)$} \\
\hline Homosexual/bissexual & $118(26.9)$ \\
\hline Heterosexual & $241(55.0)$ \\
\hline Intravenous & $8(1.8)$ \\
\hline Unknown & $71(16.2)$ \\
\hline Time since HIV seroconversion in years, mean (SD) & $9.46(4.7)$ \\
\hline CD4+ cell count $/ \mathrm{ml}$, mean (SD) & $569.1(318.4)$ \\
\hline Viral load in number of copies/ml, mean (SD) & $1.96(1.2)$ \\
\hline HDRS, mean (SD) & $6.97(8.3)$ \\
\hline \multicolumn{2}{|l|}{ Last-month alcohol use } \\
\hline None/< once a week & $364(83.1)$ \\
\hline More than once a week & $74(16.9)$ \\
\hline \multicolumn{2}{|l|}{ Last-month cocaine use } \\
\hline No & $422(96.3)$ \\
\hline Yes & $16(3.7)$ \\
\hline \multicolumn{2}{|l|}{ Last-month cannabis use } \\
\hline No & $404(92.2)$ \\
\hline Yes & $34(7.8)$ \\
\hline
\end{tabular}

$\mathrm{SD}=$ standard deviation; US = United States; HDRS = Hamilton Depression Rating Scale; HIV = human immunodeficiency virus. *Mean annual income of those who were currently working or receiving a pension.

In comparison with patients who reported homosexual/bisexual HIV transmission, those who reported heterosexual transmission or an unknown route had a lower likelihood of being non-adherent (more than 50\% and 90\%, respectively). Past non-adherent patients had lower CD4+ cell counts than adherents. Reports of last-month alcohol use more than once a week were marginally associated with past non-adherence to ART $(\mathrm{OR}=1.04$; 95\% CI: 0.63-1.72).

\section{Last-week non-adherence}

One hundred and sixteen patients (26.5\%) reported having adhered to ART over the past week. Almost $80 \%$ of the adherent patients had undetectable viral loads (Pearson chisquare value $=7.89 ; \mathrm{P}=0.005 ; \mathrm{OR}=1.94 ; 95 \% \mathrm{CI}: 1.21-3.09$ ) Recent non-adherence was significantly associated with younger age and higher numbers of HIV RNA copies, in comparison with recent adherent patients. Patients who reported recent nonadherence also showed higher HDRS scores than the adherent patients. Last-month alcohol use more than once a week was also marginally correlated with recent non-adherence. All the data on adherence, past non-adherence and recent non-adherence is presented in Table 2 .

\section{Multiple regression results}

Past non-adherence to ART was independently predicted by older age and lower CD4+ cell count. Homosexual/bisexual transmission was also significantly and independently associated with non-adherence, in comparison with those who reported heterosexual and unknown transmission routes. For recent nonadherence to ART, the strongest independent predictors were younger age and higher HDRS scores. Recent non-adherence was also independently predicted by higher numbers of HIV RNA copies (Table 3 ).

\section{DISCUSSION}

In this sample of HIV individuals on ART, adherence was evaluated as two patterns: over the past three months and over the past week, which were defined as treatment interruption and missed doses, respectively. The rate of recent non-adherence $(26.4 \%)$ was close to what was observed by Nemes et al. (25\%) in 322 healthcare clinics in Brazil, ${ }^{28}$ but lower than what was observed in other Brazilian studies (36.9\% and 37.2\%), ${ }^{21,22}$ with different methodologies. In a randomized controlled trial, the percentages of non-adherence measured by means of Medication Event Monitoring System (MEMS) caps ranged from $35.4 \%$ to $50.9 \%,{ }^{29}$ which was similar to the results for past non-adherence in the present study.

The frequency of past non-adherence was almost twice the recent frequency. Since past adherence covered a longer time interval, this result was not unexpected. Additionally, the past and recent non-adherence results came from different individuals, as shown by the correlation results, and it is probably correct to say that they came from different treatment behaviors.

Previous studies have shown that the higher the adherence is, the lower the likelihood of virological failure will be, ${ }^{30,31}$ as seen in the binary association, with almost twice the likelihood of having a detectable viral load among patients who missed doses. Since the viral load is a faster and more accurate method for signaling the clinical consequences of treatment failure ${ }^{32}$ than the CD4+ cell count, which may be related to other immunological variations, ${ }^{33}$ it is possible that a recent non-adherence pattern will also have the same ability, compared with past non-adherence. 
Table 2. Bivariate associations between predictive variables and past and recent non-adherence to antiretroviral therapy at the HIV treatment center, in 2007

\begin{tabular}{|c|c|c|c|c|c|}
\hline \multirow[t]{2}{*}{ Characteristics } & \multirow{2}{*}{$\begin{array}{c}\text { Adherents } \\
\mathrm{n}=119(27.3 \%) \\
\mathrm{n}(\%)\end{array}$} & \multicolumn{2}{|c|}{$\begin{array}{l}\text { Past non-adherence } \\
n=203(46.3 \%)\end{array}$} & \multicolumn{2}{|c|}{$\begin{array}{l}\text { Recent non-adherence } \\
n=116(26.4 \%)\end{array}$} \\
\hline & & n (\%) & Crude OR (95\% CI) & n (\%) & Crude OR $(95 \% \mathrm{CI})$ \\
\hline Age in years, mean (SD) & $41.6(7.3)$ & $42.5(8.6)^{*}$ & $1.06(1.00-1.05)^{*}$ & $39.9(7.3)$ & $0.96(0.93-0.99)^{*}$ \\
\hline Male & $61(53)$ & $103(45.6)$ & Ref. & $63(27.9)$ & Ref. \\
\hline Female & $58(48)$ & $100(47.2)$ & $1.06(0.73-1.55)$ & $56(26.4)$ & $0.92(0.60-1.41)$ \\
\hline \multicolumn{6}{|l|}{ Race/ethnicity, n (\%) } \\
\hline Black & $20(17)$ & $36(47.4)$ & $0.76(0.31-1.87)$ & $17(22.4)$ & $0.79(0.42-1.48)$ \\
\hline Mixed & $22(18.7)$ & $41(45.6)$ & $0.81(0.31-2.15)$ & $27(30.0)$ & $1.13(0.65-1.97)$ \\
\hline Other & $6(4.7)$ & $11(52.4)$ & $0.76(0.29-1.97)$ & $5(23.8)$ & $0.80(0.27-2.32)$ \\
\hline \multicolumn{6}{|l|}{ Education, n (\%) } \\
\hline Basic & $83(70.2)$ & $163(49.2)$ & Ref. & $89(26.9)$ & Ref. \\
\hline Higher & $36(29.8)$ & $40(37.4)$ & $0.61(0.39-0.96)^{*}$ & $30(28.0)$ & $1.05(0.65-1.72)$ \\
\hline Annual income in US dollars, mean (SD) & $9,485,0(10,858.2)$ & $8,012.5(9,401.1)$ & $1.00(1.00-1.00)$ & $8,009.1(9,814.7)$ & $1.00(1.00-1.00)$ \\
\hline \multicolumn{6}{|l|}{ Conjugal status, $\mathrm{n}(\%)$} \\
\hline Living together & $32(26.9)$ & $64(46.0)$ & Ref. & $39(28.1)$ & Ref. \\
\hline Living alone & $87(73.1)$ & $139(46.5)$ & $1.01(0.68-1.52)$ & $80(26.8)$ & $0.93(0.59-1.46)$ \\
\hline \multicolumn{6}{|l|}{ HIV transmission route, $\mathrm{n}(\%)$} \\
\hline Homosexual/bisexual & $37(31)$ & $46(39.0)$ & Ref. & $38(32.2)$ & Ref. \\
\hline Heterosexual & $61(51.5)$ & $115(47.7)$ & $0.46(0.25-0.85)^{*}$ & $63(26.1)$ & $0.69(0.41-1.16)$ \\
\hline Intravenous & $4(2.9)$ & $1(12.5)$ & $0.66(0.39-1.14)$ & $2(25.0)$ & $0.98(0.18-5.25)$ \\
\hline Unknown & $17(14.6)$ & $41(57.7)$ & $0.10(0.01-.89)^{*}$ & $16(22.5)$ & $0.53(0.26-1.10)$ \\
\hline Time since HIV seroconversion in years, mean (SD) & $9.45(4.2)$ & $9.6(5.3)$ & $1.01(0.97-1.05)$ & $9.39(4.4)$ & $0.99(0.95-1.04)$ \\
\hline CD4+ cell count $/ \mathrm{ml}$, mean (SD) & $615.9(344.8)$ & $527.5(299.2)^{*}$ & $0.99(0.99-1.00)^{*}$ & $544.3(339.7)$ & $1.00(0.99-1.00)$ \\
\hline \multicolumn{6}{|l|}{ Last-month cannabis use, $\mathrm{n}(\%)$} \\
\hline No & $109(91.2)$ & $190(47.0)$ & Ref. & $107(26.5)$ & Ref. \\
\hline Yes & $10(8.8)$ & $13(38.2)$ & $0.69(0.34-1.43)$ & $12(35.3)$ & $1.51(0.72-3.16)$ \\
\hline
\end{tabular}

${ }^{*} \mathrm{P}<0.05,{ }^{\mathrm{t}} \mathrm{P}<0.01$. OR = odds ratio; $\mathrm{Cl}=$ confidence interval; $\mathrm{SD}=$ standard deviation; US = United States; HDRS = Hamilton Depression Rating Scale; HIV = human immunodeficiency virus; Ref. = 1.0.

More importantly, since adherence does not provide a full explanation for the observed variations in treatment responses, ${ }^{34}$ it was observed that the effect of non-adherence, as a consequence of missed doses, was related to growing levels of depressive symptoms. This correlation is well known, but it has been suggested that some methodological issues concerning the time of recall, measurements of depression and past and present history of depression act as misleading factors. ${ }^{35}$ In our study, HDRS was used to measure depression symptoms over the last week, and it is likely that measurements of both recent adherence and depressive symptoms would express a pattern of missed dose frequency, and would also be related to the detectable viral load. ${ }^{36}$
Along with the impact of depressive symptoms on the immune system, the influence of alcohol and other drug use over the past month was not related to recent non-adherence to ART. Last-month alcohol use was measured as none/less than once a week or as more than once a week. This last measurement admits a range of patterns of consumption that might be acting as a confounding factor. Nevertheless, previous studies have shown that adherence would be higher among alcohol users than among abstainers (or those who drank relatively less). ${ }^{37}$

Concerning younger age, some difficulties in taking medication at weekends because of stigma, ${ }^{38}$ or due to alterations in these individuals' regular schedules or involvement in other 
Table 3. Multiple logistic regression results for predictable variables and past and recent non-adherence to ART among patients at the HIV treatment center in 2007

\begin{tabular}{|c|c|c|c|c|c|c|c|c|c|c|}
\hline & \multicolumn{5}{|c|}{ Past non-adherence } & \multicolumn{5}{|c|}{ Recent non-adherence } \\
\hline & B & SE & Wald & OR & $95 \% \mathrm{Cl}$ & B & SE & Wald & OR & $95 \% \mathrm{Cl}$ \\
\hline Age in years & 0.028 & 0.012 & 5.07 & $1.02 *$ & $1.00-1.05$ & -0.039 & 0.014 & 7.50 & $0.96^{+}$ & $0.93-0.98$ \\
\hline \multicolumn{11}{|l|}{ Education } \\
\hline Higher & 0.321 & 0.012 & 1.72 & 1.37 & $0.85-2.22$ & - & - & - & - & - \\
\hline \multicolumn{11}{|l|}{ HIV transmission route } \\
\hline Intravenous & -0.27 & 0.28 & 0.92 & 0.76 & $0.44-1.32$ & - & - & - & - & - \\
\hline Unknown & -2.27 & 1.10 & 4.28 & $0.10^{*}$ & $0.01-0.88$ & - & - & - & - & - \\
\hline CD4+ cell count & -0.001 & 0.000 & 5.78 & $0.99 *$ & $0.99-1.00$ & - & - & - & - & - \\
\hline Viral load & - & - & - & - & - & 0.195 & 0.082 & 5.66 & $1.21^{*}$ & $1.03-1.42$ \\
\hline HDRS & - & - & - & - & - & 0.042 & 0.013 & 11.0 & $1.04^{+}$ & $1.01-1.07$ \\
\hline
\end{tabular}

${ }^{*} \mathrm{P}<0.05,{ }^{\mathrm{t}} \mathrm{P}<0.01$. OR = odds ratio; $\mathrm{Cl}=$ confidence interval; HDRS = Hamilton Depression Rating Scale; HIV = human immunodeficiency virus. $\mathrm{B}=$ beta; $\mathrm{SE}=$ standard error; Wald $=$ Wald test.

activities, might lead to missing doses of ART. Additionally, the $\mathrm{U}$-shape between age and depressive symptoms ${ }^{39}$ could have an exponential effect on adherence.

Past adherence or treatment interruption is more likely to be affected by recall errors than is recent adherence, which may be strengthened by the independent association of older age and unknown transmission route among non-adherent patients over this interval. However, multivariate analysis also showed the magnitude of the correlation of lower CD4+ count and heterosexual transmission with treatment interruption. Taking into account the changes in the demographics of HIV infection in Brazil, with the growth of heterosexual transmission and increasing life expectancy, ${ }^{40}$ it is likely that such changes require shifts in prevention and care. ${ }^{41}$

Because the period used to define past adherence comprised a three-month interval, the CD4+ cell count results might have expressed prior conditions, and even previous virological elevations. It is also possible that an age-related effect and the sparseness of preventive actions for heterosexual individuals might explain the joint effect of poor immune response.

Some limitations of the present study need to be discussed. Firstly, although self-reporting is affected in several ways by personal difficulties, it is generally credible $e^{42}$ and correlates with clinical data, ${ }^{31}$ as seen in our study. As recommended by Simoni et al., ${ }^{43}$ we proposed item standardization for the SMAQ, through applying the last two questions, which cover recent adherence. This allowed the patients to distinguish between missing doses and treatment interruption.

Additionally, the sample studied was not randomly selected from all HIV patients in Brazil, since the patients were selected from a specific center. Nevertheless, this study sample was not statistically different from the center population. Even so, further generalization is limited to similar populations.

These results do not allow the extension of such findings to a clinical condition of major depression, which requires a full clinical evaluation, and presumably a specific treatment. Notwithstanding this, our results emphasize that clinicians should integrate the delivery of clinical care, targeted interventions $^{44}$ and counseling ${ }^{45,46}$ against depressive symptoms through regular appointments, in order to avoid poorer outcomes. These findings should stimulate clinicians to evaluate depression when the patient is not complying with the treatment or is in a situation of treatment failure.

Future research should replicate these findings using a standardized clinical diagnosis of depression.

\section{CONCLUSION}

Our results show that depressive symptoms were related to the presence of patterns of missing doses, non-adherence to treatment and virological failure, which should be targeted by clinicians through regular appointments.

\section{REFERENCES}

1. Bangsberg DR, Perry S, Charlebois ED, et al. Non-adherence to highly active antiretroviral therapy predicts progression to AIDS. AIDS. 2001;15(9):1181-3.

2. Wood E, Hogg RS, Yip B, et al. Effect of medication adherence on survival of HIV-infected adults who start highly active antiretroviral therapy when the CD4+ cell count is 0.200 to $0.350 \times 10$ (9) cells/L. Ann Intern Med. 2003;139(10):810-6. 
3. Fine RN, Becker $Y$, De Geest $S$, et al. Nonadherence consensus conference summary report. Am J Transplant. 2009;9(1):35-41.

4. Carrieri MP, Leport C, Protopopescu C, et al. Factors associated with nonadherence to highly active antiretroviral therapy: a 5-year followup analysis with correction for the bias induced by missing data in the treatment maintenance phase. J Acquir Immune Defic Syndr. 2006;41(4):477-85.

5. Lucas GM, Griswold M, Gebo KA, et al. Illicit drug use and HIV-1 disease progression: a longitudinal study in the era of highly active antiretroviral therapy. Am J Epidemiol. 2006;163(5):412-20.

6. Palepu A, Raj A, Horton NJ, et al. Substance abuse treatment and risk behaviors among HIV-infected persons with alcohol problems. J Subst Abuse Treat. 2005;28(1):3-9.

7. Hinkin $\mathrm{CH}$, Barclay TR, Castellon SA, et al. Drug use and medication adherence among HIV-1 infected individuals. AIDS Behav. 2007;11(2):185-94.

8. Bouhnik $A D$, Préau $M$, Vincent $E$, et al. Depression and clinical progression in HIV-infected drug users treated with highly active antiretroviral therapy. Antivir Ther. 2005;10(1):53-61.

9. Ciesla JA, Roberts JE. Meta-analysis of the relationship between HIV infection and risk for depressive disorders. Am J Psychiatry. 2001;158(5):725-30.

10. Friedman $H$, Pross $S$, Klein TW. Addictive drugs and their relationship with infectious diseases. FEMS Immunol Med Microbiol. 2006;47(3):330-42.

11. Leserman J. Role of depression, stress, and trauma in HIV disease progression. Psychosom Med. 2008;70(5):539-45.

12. Klinkenberg WD, Sacks S; HIV/AIDS Treatment Adherence, Health Outcomes and Cost Study Group. Mental disorders and drug abuse in persons living with HIV/AIDS. AIDS Care. 2004;16 Suppl 1:S22-42.

13. National Institutes of Health. Office of AIDS Research. Advisory Council, United States. Public Health Service. Guidelines for the use of antiretroviral agents in HIV-1-infected adults and adolescents. Available from: http://aidsinfo.nih.gov/contentfiles/lvguidelines/ adultandadolescentgl.pdf. Accessed in 2014 (Jan 28).

14. Liu H, Golin CE, Miller LG, et al. A comparison study of multiple measures of adherence to HIV protease inhibitors. Ann Intern Med. 2001;134(10):968-77.

15. Carrieri P, Cailleton V, Le Moing V, et al. The dynamic of adherence to highly active antiretroviral therapy: results from the French National APROCO cohort. J Acquir Immune Defic Syndr. 2001;28(3):232-9.

16. Knobel H, Urbina O, González A, et al. Impact of different patterns of nonadherence on the outcome of highly active antiretroviral therapy in patients with long-term follow-up. HIV Med. 2009;10(6):364-9.

17. Villes V, Spire B, Lewden C, et al. The effect of depressive symptoms at ART initiation on HIV clinical progression and mortality: implications in clinical practice. Antivir Ther. 2007;12(7):1067-74.

18. Brigido LF, Rodrigues R, Casseb J, et al. Impact of adherence to antiretroviral therapy in HIV-1-infected patients at a university public service in Brazil. AIDS Patient Care STDS. 2001;15(11):587-93.
19. Melchior R, Nemes MIB, Alencar TMD, Buchalla CM. Desafios da adesão ao tratamento de pessoas vivendo com HIV/Aids no Brasil [Challenges of treatment adherence by people living with HIV/AIDS in Brazil]. Rev Saude Publica. 2007;41 (supl 2):87-93.

20. Silva MCF, Ximenes RAA, Miranda Filho DB, et al. Fatores preditivos de não-adesão à terapia antiretroviral [Risk-factors for nonadherence to antiretroviral therapy]. Rev Inst Med Trop São Paulo. 2009;51(3):135-9.

21. Bonolo Pde F, Machado CJ, César CC, Ceccato MD, Guimarães MD. Vulnerability and non-adherence to antiretroviral therapy among HIV patients, Minas Gerais State, Brazil. Cad Saude Publica. 2008;24(11):2603-13.

22. Campos LN, Guimarães MD, Remien RH. Anxiety and depression symptoms as risk factors for non-adherence to antiretroviral therapy in Brazil. AIDS Behav. 2010;14(2):289-99.

23. Malta M, Magnanini MM, Strathdee SA, Bastos Fl. Adherence to antiretroviral therapy among HIV-infected drug users: a metaanalysis. AIDS Behav. 2010;14(4):731-47.

24. Paz LC, Pereira GF, Pinto VM, et al. Nova definição de casos de sífilis congênita para fins de vigilância epidemiológica no Brasil, 2004 [New case definition of congenital syphilis for epidemiological surveillance purposes in Brazil, 2004]. Rev Bras Enferm. 2005;58(4):486-7.

25. Folstein MF, Folstein SE, McHugh PR. "Mini-mental state". A practical method for grading the cognitive state of patients for the clinician. $J$ Psychiatr Res. 1975;12(3):189-98.

26. Hamilton M. A rating scale for depression. J Neurol Neurosurg Psychiatry. 1960;23:56-62.

27. Knobel H, Alonso J, Casado JL, et al. Validation of a simplified medication adherence questionnaire in a large cohort of HIVinfected patients: the GEEMA Study. AIDS. 2002;16(4):605-13.

28. Nemes Ml, Alencar TM, Basso CR, et al. Assessment of outpatient services for AIDS patients, Brazil: comparative study 2001/2007. Rev Saude Publica. 2013;47(1):137-46; discussion 146.

29. Basso CR, Helena ET, Caraciolo JM, Paiva V, Nemes MI. Exploring ART intake scenes in a human rights-based intervention to improve adherence: a randomized controlled trial. AIDS Behav. 2013;17(1):181-92.

30. Paterson DL, Swindells S, Mohr J, et al. Adherence to protease inhibitor therapy and outcomes in patients with HIV infection. Ann Intern Med. 2000;133(1):21-30.

31. Nieuwkerk PT, Oort FJ. Self-reported adherence to antiretroviral therapy for HIV-1 infection and virologic treatment response: a metaanalysis. J Acquir Immune Defic Syndr. 2005;38(4):445-8.

32. Nachega JB, Hislop M, Dowdy DW, et al. Adherence to nonnucleoside reverse transcriptase inhibitor-based HIV therapy and virologic outcomes. Ann Intern Med. 2007;146(8):564-73.

33. Price DA, Scullard G, Oxenius A, et al. Discordant outcomes following failure of antiretroviral therapy are associated with substantial differences in human immunodeficiency virus-specific cellular immunity. J Virol. 2003;77(10):6041-9. 
34. Azar MM, Springer SA, Meyer JP, Altice FL. A systematic review of the impact of alcohol use disorders on HIV treatment outcomes, adherence to antiretroviral therapy and health care utilization. Drug Alcohol Depend. 2010;112(3):178-93.

35. Springer SA, Dushaj A, Azar MM. The impact of DSM-IV mental disorders on adherence to combination antiretroviral therapy among adult persons living with HIV/AIDS: a systematic review. AIDS Behav. 2012;16(8):2119-43.

36. Catz SL, Kelly JA, Bogart LM, Benotsch EG, McAuliffe TL. Patterns, correlates, and barriers to medication adherence among persons prescribed new treatments for HIV disease. Health Psychol. 2000;19(2):124-33.

37. Hendershot CS, Stoner SA, Pantalone DW, Simoni JM. Alcohol use and antiretroviral adherence: review and meta-analysis. J Acquir Immune Defic Syndr. 2009;52(2):180-202.

38. Rao D, Feldman BJ, Fredericksen RJ, et al. A structural equation model of HIV-related stigma, depressive symptoms, and medication adherence. AIDS Behav. 2012;16(3):711-6.

39. Sutin AR, Terracciano A, Milaneschi $Y$, et al. The trajectory of depressive symptoms across the adult life span. JAMA Psychiatry. 2013;70(8):803-11 .

40. Nakagawa F, May M, Phillips A. Life expectancy living with HIV: recent estimates and future implications. Curr Opin Infect Dis. 2013;26(1):17-25.

41. Hall HI, Espinoza L, Benbow N, Hu YW; Urban Areas HIV Surveillance Workgroup. Epidemiology of HIV infection in large urban areas in the United States. PloS One. 2010;5(9):e12756.

42. Bangsberg DR, Hecht FM, Clague $H$, et al. Provider assessment of adherence to HIV antiretroviral therapy. J Acquir Immune Defic Syndr. 2001;26(5):435-42.

43. Simoni $J M$, Kurth $A E$, Pearson $C R$, et al. Self-report measures of antiretroviral therapy adherence: A review with recommendations for HIV research and clinical management. AIDS Behav. 2006;10(3):227-45.

44. Amico KR, Orrell C. Antiretroviral therapy adherence support: recommendations and future directions. J Int Assoc Provid AIDS Care. 2013;12(2):128-37.

45. Fisher JD, Fisher WA, Cornman DH, et al. Clinician-delivered intervention during routine clinical care reduces unprotected sexual behavior among HIV-infected patients. J Acquir Immune Defic Syndr. 2006;41(1):44-52.

46. Gardner LI, Marks G, O'Daniels CM, et al. Implementation and evaluation of a clinic-based behavioral intervention: positive steps for patients with HIV. AIDS Patient Care STDS. 2008;22(8):627-35.

Sources of funding: This study was supported by the National STD/AIDS Program of the Ministry of Health (Convocation Notice no. 01/2005)

Conflict of interest: None
Date of first submission: July 30, 2013

Last received: February 13, 2014

Accepted: February 17, 2014

\section{Address for correspondence:}

Claudia Siqueira Tufano

Ricardo Amaral

Universidade de São Paulo — Instituto de Psiquiatria

Programa do Grupo Interdisciplinar de Estudos de Álcool e Drogas (GREA)

Rua Ovídio Pires de Campos, 785

São Paulo (SP) - Brasil

CEP 05403-010

Tel/Fax. (+55 11) 2661-7892

E-mail:dtufano@terra.com.br

E-mail: ricardo.amaral@hc.fm.usp.br 